\title{
Auditor's Risk Assessment of Independent Directors in Nigeria
}

\author{
Abdulmalik Salau*, and Ayoib Che Ahmad \\ Tunku Puteri Intan Safinaz School of Accountancy, Universiti Utara Malaysia
}

\begin{abstract}
The objective of this study is to investigate the external auditor's risk assessment of independent directors in Nigeria. The study utilized data from 94 non-financial listed companies on the Nigerian Stock Exchange for the periods 2008-2013. The study used cross-sectional timeseries feasible generalized least square regression, which account for heteroscedasticity and autocorrelation to test the influence independent non-executive director on auditor pricing decision in Nigeria. Our result indicates that the proportion of independent non-executive director has a positive relationship with audit fees, suggesting that this class of directors is priced high by the Nigerian auditors. These findings have both policy and practical implication on corporate governance. For instance, future regulatory reforms could consider collaborative board model instead of the insistence on more independent director presence in the boardroom.
\end{abstract}

\section{Introduction}

An important corporate governance mechanism which corporate governance codes have given more emphasis since the Enron scandal in the early 2000 has been the independence of the board of directors. Board independence through the separation of the position of the CEO and Chairman and the composition of the board with majority of non-executive independent directors is highlighted in codes of corporate governance and some empirical studies to improve board oversight function. [1, 2, 3; 4 \& 5] all provide empirical assertions on the monitoring prowess of non-executive independent directors from different perspective of organisation outcome consistent with the agency theory. Nevertheless, in the recent time, there are countervailing arguments with respect to monitoring prowess of independent directors. Notably, Fogel et al. asserted that, "there is no predicate either in logic or in experience to suggest that a majority of independent director will guarantee good corporate governance or better financial return of shareholders" [6] (pg. 35). Based on their findings, [6], found an inconclusive evidence that the dominance of independent directors improves firms' financial performance. Similarly, [7] finding revealed that the presence of independent directors does not improve board monitoring in family owned companies While, [4] documented that independent directors reduce earnings ability to predict future cash flows in the Malaysian context. According to [8], the independent directors do not have an adequate understanding of the daily operation of the company. This is because in

\footnotetext{
*Corresponding author: abdmaliksalau@gmail.com
} 
most cases their presence is only at the instance of the board meeting. As a result, their monitoring prowess is weakened. Based on the foregoing countervailing argument on the monitoring prowess of non-executive independent director, this study investigates the impact of non-executive independent directors on the assessed inherent risk perceived by the Nigerian auditors as revealed in the audit fees charged from the supply perspective like prior studies $[9 ; 10]$. For over three decades the factors that determined audit fees has stimulates researchers interest due to the possibility of auditors' independence impairment [11]. However, despite the abundant studies on audit fees, governance and regulation, the overall results have produced conflicting results due to the complex nature of the variables [12]. Logically, from the audit supply point of view, sound corporate governance in companies indicates that the overall control system is strong, effective and efficient towards ensuring sound reporting quality. Accordingly, there will be a negative relationship between governance mechanisms and audit fees which implies that strong control environment reduces audit fees because the auditor perceived client inherent risk low [9].

Contrary to the findings of $[9,10]$ our finding suggests that auditor assessment of board composition risk affect audit pricing and that the proportion of independent directors tends to increase audit fees. Our findings and argument as well contradict the findings of [5] that argue from the point of view of audit demand and documented that the presence of increase audit fees due to their high demand. Although independent directors supposedly enhance board monitoring, in the recent time critics argues that their presence does not necessarily enhance board independence, as they might not be truly independent. As documented in the findings of [12]" the traditional role and the overbearing influence of family owners in the context of Nigeria might limit the oversight function and independence of the board. Consistent with this postulation, our findings suggest that the presence of independent directors might not be a panacea for weak governance.

The contribution of this study is that it provides further evidence from a less studied market, Nigeria and thus provides an avenue for future studies most especially from the perspective of developing countries whose corporate governance structure are entirely different from those of the developed nations. Although, there are studies in this area from some emerging economies however, the corporate governance landscape in countries varies hence, limiting the generalizability of the frequently researched Anglo-American system in the Nigeria setting. In the sense that the indigenization policy embarked upon by the Nigerian government as some point in time lead to majority share ownership mostly held by founding families who have significant influence on board and on management [13]. Accordingly, the assumptions of market efficiency, competitive market and market mechanisms which agency theory presuppose are not validly applicable in the Nigerian where ownership concentrated [13]. Moreover, the code of corporate governance that was revised in 2011 just codified the requirement for the inclusion of non-executive independent directors and some companies are yet to comply with this requirement. Notwithstanding the poor compliance rate, the independence of the purported independent director is susceptible to impairment due to the control retain by founding family. Apparently, the distinctiveness of the Nigeria corporate governance environment from the corporate governance environment of previous study as highlighted above provides an additional opportunity to extend the body of knowledge.

The remaining part of the study is as follows: section 2 outline prior literature and hypotheses development. We discuss the sample selection procedure and research design in section 3 and section 4 contains the presentation of result. The final section concludes the study. 


\section{Literature review and hypothesis development}

Based on [14] traditional audit fees model several audit fees studies established the scope of audit, the complexity of audit work and the risk associated with an audit as the primary determinants of audit fees. Consistent with these three factors, audit fees-governance related studies suggest that the strength of client governance environment significantly influence the scope and risk associated with an audit engagement [9]. For instance, a strong governance environment will reduce audit risk that will subsequently translate into less audit scope hence a reduction in audit fees and vice versa. Several characteristics of a strong governance environment have been identified in literature and Codes of Corporate Governance among which is the extent of board independence (i.e. non-executive independent directors). The advocates of independent non-executive directors claimed that their presence on board enhance the board of director's incentive to monitor and discharge their oversight function because of the absence of any contractual relationship between them and the management. Some of the empirical evidence that support this view are [16] that reported that independent directors improve corporate reporting quality and [9] whom noted that the presence of non-executive independent director in boardroom enhance auditors' reliance on client accounting system and thus reduce the amount paid as audit fees. While there are several empirical studies that established the positive outcome of the presence of non-executive independent directors on board other study have found that their presence does not necessarily improve board outcome but rather contribute negatively. For instance, [17] found a positive relationship between corporate failure propensity and the proportion of independent non-executive director on corporate board. Since empirical findings regarding the effectiveness of independent non-executive director are inconsistent, this present study posits that:

H1: There is a relationship between the proportion of independent non-executive director in boardroom and audit fees.

\section{Methodologies}

\subsection{Sample selection and data}

This study used the sample of Nigerian public listed companies with the exclusion of all financial companies. In addition to financial companies, this study as well excludes companies with missing annual report and missing information. Accordingly, the final sample consist 94 companies listed on the Nigerian Stock Exchange between the years of 2008 and 2013 leading to 426 unbalanced observations.

\subsection{Regression model and specification}

This study employs panel estimation approach to examine the hypotheses regarding the relationship between corporate governance characteristic and audit fees. This approach is considered more suitable for a group of firms listed on the Nigerian Stock Exchange due to the problem of bias caused by unobserved heterogeneity. Due to the presences of contemporaneous correlation and heteroscedasticity as characterised in panel data, this study employs Feasible Generalized Least Square (FGLS) to correct for this problem. However, before then, the Breusch-Pagan Lagrange Multiplier test rejects the null hypothesis of no effect in the cross sectional unit over the period of time as the P-value is 0.000 suggesting that pool OLS is not appropriate. The Hausman test result shows that FE 
model is preferable to the random effect model. Accordingly, the model as adopted from Sminunic [14] is developed as follows:

$$
\begin{aligned}
\text { LOGAF }_{i t}=\alpha_{i t} & +\beta_{1} \text { IND }_{i t}+\beta_{2} \text { LOGTA }_{i t}+\beta_{3} \text { BIG }_{i t} \\
& +\beta_{4} \text { CA }_{i t}+\beta_{5} \text { QUICKRATIO }_{i t}+\beta_{6} \text { GEARING }_{i t} \\
& +\beta_{7} \text { BUSSEG }_{i t}+\beta_{8} \text { INVT }_{-i t}+\beta_{9} \text { ROA }_{i t}+\beta_{10} \text { LOSS }_{i t} \\
& +\beta_{11} \text { BUSY Y }_{i t}+\beta_{12} \text { DELAY }_{i t}+\beta_{13} \text { BLOCKSHR }_{i t} \\
& +\beta_{14} \text { INDUSTRY EFFECT }_{i t}+\beta_{15} \text { YEAR EFFECT }_{i t}+\varepsilon_{i t}+\mu_{i t}
\end{aligned}
$$

Where, log audit fees (LOGAFit) = the amount paid as audit fees by client $\mathrm{i}$ in year $\mathrm{t}$; independent non-executive director (IND_it) = percentage of directors in the boardroom that are independent. Consistent with earlier studies we control for client size, complexity, risk and auditor related attribute. Natural log of total asset in thousand (LOGTAit) = client size. Auditor related attribute proxy by audit quality $($ BIG4it) = dummy variable representing big four audit firm, coded 1 if the firm is audited by one of the big audit firm or 0 otherwise; busy period (BUSYit) $=$ dummy variable representing client that has March and December as their financial year end, coded 1 if the client financial year end falls in these month or 0 otherwise; audit lag (DELAYit) = the number of days between financial year end and the day the audit report was signed. Client risk is proxy by (CAit) $=$ current asset to current liability; quick ratio (QUICKRATIOit) $=$ current asset minus inventory scaled by current liability and loss (LOSSit) $=$ dummy variable representing client who recoded negative earning after interest and tax. Client complexity is proxy by business segment $($ BUSEGit $)=$ number of client business segment; Inventory $($ INVT_it) = balance sheet value of closing inventory scaled by total asset. Measure of client performance $($ ROAit $)=$ net income divided by total asset. Form of ownership (BLOCKSHRit) = company outstanding share more than $5 \%$ held by individual block shareholders. Finally, we control for variation between year and industry.

\section{Empirical analyses}

Table 1 present the result of the cross-sectional time-series FGLS used to examine auditors' risk assessment of independent directors in Nigeria and the result indicates that that audit fees is positively related to the proportion of independent director (IND_) on board $(\mathrm{P}<0.01)$ and this is consistent the current study postulation. With respect to the control, variables with the exception of few variables are consistent with theory [11]. Client size measured by log total asset (LOGTA) has a positive relationship with audit fees. Similarly, client complexity measured by number of business segment (BUSSEG) and inventory (INVT_) as well has a positive relationship with audit fees, suggesting that complex client pay more consistent with agency theory. Client risk proxy by current asset ratio (CA) and GEARING reveals a negative coefficient while quick ratio (QUICKRATIO) exhibit positive relationship with audit fees. Profitability measured by LOSS has positive relationship with audit fees. BLOCKSHR exhibit a negative relationship with audit. Auditor related attributes BIG4 and BUSY as expected have a positive relationship with audit fees. 
Table 1. Regression Result for audit fees

\begin{tabular}{lc}
\hline Variable & Model \\
\hline CON & 1.16 \\
& $\left(13.20^{* * *}\right)$ \\
IND_ & 0.20 \\
LOGTA & $\left(5.12^{* * *}\right)$ \\
& 0.37 \\
BIG4 & $\left(33.37^{* * *}\right)$ \\
& 0.32 \\
CA & $\left(18.29^{* * *}\right)$ \\
& -0.06 \\
QUICKRATIO & $\left(-2.66^{* * *}\right)$ \\
BUSSEG & 0.06 \\
& $\left(2.41^{* * *}\right)$ \\
INVT_ & 0.02 \\
ROA & $\left(3.63^{* * *}\right)$ \\
& 0.05 \\
LOSS & -0.86 \\
& 0.00 \\
GEARING & -0.16 \\
BUSY & 0.06 \\
& $\left(3.12^{* * *}\right)$ \\
DELAY & -0.01 \\
BLOCKSHR & $\left(-2.04^{* * *}\right)$ \\
YEAR EFFECT & 0.06 \\
INDUSTRY EFFECT & $\left(3.94^{* * *}\right)$ \\
ADJUSTED R-SQUARE & 0.00 \\
F-STATISTIC & $\left(-1.77^{* *}\right)$ \\
\hline No. & -0.01 \\
& $\left(-12.69^{* * *}\right)$ \\
YES \\
YES \\
\end{tabular}

Notes: *** Significant at 1 per cent level; **, significant at 5 per cent level; ${ }^{*}$, significant at 10 per cent (twotailed). The dependent variable is log of audit fees (LOGAF). A continuous variable that represent the amount collected as auditor's remuneration in Naira.

\section{Discussion of findings and conclusion}

In this study, we investigated the Nigerian auditor risk assessment of non-executive independent directors of public listed companies on the Nigerian Stock Exchange. Towards the set objective, we employ cross-sectional time-series FGLS regression which controls the issues of heteroscedasticity and autocorrelation on a sample of 94 public listed Nigerian companies. The findings indicate that an increase in the proportion of independent director increase the amount paid as audit fees. Overall, the result reveals some weakness in independent directors' performance of their advisory and monitoring role has consequence for auditor risk assessment hence the audit fees. The findings of this study have implication for audit fees literature. Against prior studies that examined the relationship between independent board and auditor pricing decision from the supply perspective, the present study finding indicates that the presence of non-executive independent director does not necessary guarantee good corporate governance. Therefore, future research most especially 
those undertaken in the less developed market with prevalence of family ownership could consider the collaborative board model. Because, recent literatures [15] have begun to fault the one-dimensional view of board role as dominant in literature and recommends that studies should consider other board responsibility in relation to auditing. In addition, future study could embark on a more in-depth study by segregating the so called independent director by the extent of their true independence to determine how it affect the risk perception of external auditors. This is imperative due to recent literatures that questions the genuineness of the so called independent directors on corporate board.

\section{References}

1. S. T., Petra, The international journal of business in society, 6, 2, 107-115 (2006).

2. W., Beekes, P., Pope, S., Young, (2004). Corporate Governance: An International Review, 12, 1, 47-59 (2004).

3. A. S., Ahmed, S. Duellman, Journal of accounting and economics, 43, 2, 411-437 (2007).

4. R.A., AL-Dhamari, K. N. I. K. Ismail, Jurnal Pengurusan, 41, 43-55 (2014).

5. C.S., Armstrong, J. E., Core, W. R. Guay, Journal of Financial Economics, 113, 3, 383-403, (2014).

6. E. M. Fogel, A. M. Geier, Del. J. CorP. 1., 32, 33 (2007).

7. N., Abdullah, S., Z.M., Yusof, \& M. N. M Nor, Managerial Auditing Journal, 25, 6, 526-552 (2010).

8. R.J., Gilson, R. Kraakman, Stanford Law Review, 863-906, (1991).

9. J.S. Tsui, B. Jaggi, F.A Gul, Journal of Accounting, Auditing \& Finance, 16, 3, 189208 (2001).

10. B, Muniandy, (2007). Managerial Auditing Journal, 22, 7, 716-728 (2007).

11. O.S. Abdulmalik, A. Ahmad, (2016). DLSU Business \& Economics Review, 26, 1, (2016).

12. D. C. Hay, W.R Knechel, N. Wong, Contemporary accounting research, 23,1, 141191, (2006).

13. E., Adegbite, International Business Review, 24, 2, 319-330, (2015).

14. D.A., Simunic, Journal of accounting research, 161-190, (1980)

15. J. R., Cohen, G., Krishnamoorthy, A.M., Wright, A., Auditing: A Journal of Practice \& Theory, 27,2, 181-198, (2008).

16. L., Setia-Atmaja , J., Haman, G., Tanewski, The British Accounting Review, 43, 3 , 230-246 (2011).

17. H. H., Hsu, C. Y. H, Wu, The British Accounting Review, 46, 3, 215-227 (2014). 